\title{
International Experience in Upper Echelon Theory: Literature Review
}

\author{
Dino Đerđa \\ Dea Flores d.o.o.
}

\section{Abstract}

Background: The international experience of top managers is an evolving research within the upper echelon theory; therefore this literature review summarizes everything made so far. Objectives: The purpose of this paper is to provide a literature review of international experience within the theory of the upper echelons. Methods/Approach: We reviewed the literature from the beginning of the theory formation and tried to understand the direction in which it develops, particularly in the context of international experience. We conducted a bibliometric analysis in order to understand the research area better. Results: We have found that 38 papers were published in 25 different journals by 72 authors. We have concluded that the area of research is very narrow and that most of the research is concentrated on finding out the impact of demographic characteristics and international experience of top managers on internationalization strategy mostly with MNC-s. Conclusions: After two decades of international experience in the upper echelon theory there is a significant possibility of uniformity of the theory but only if researchers are able to prove equal results among different countries.

Keywords: upper echelon theory; international experience; demographic characteristics; content analysis; top management team

JEL classification: F23, M16

Paper type: Research paper

Received: March 28, 2017

Accepted: Jun 25, 2017

Citation: Đerđa, D. (2017), "International Experience in Upper Echelon Theory: Literature Review", Business Systems Research, Vol. 8, No. 2, pp. 126-142.

DOI: 10.1515/bsrj-2017-0021

\section{Introduction}

The international experience of top managers and their influence within the upper echelon theory increasingly emerged in the last twenty years. Upper echelon theory researchers investigated the impact of international experience on several aspects of the company's functioning, with the different focus: impact to the level of internationalization, to the form of internationalization, to the internationalization strategy and others. The purpose of this paper is to summarize the research in this area in order to find out the main groups of the research and detect the future research directions. 
The contribution of this literature review is reflected in the discussion of the research from the field of international experience within the theory of upper echelon, in the period from 1984 (when upper echelon theory was established) until 2016. The contribution of this literature review is also reflected in the recognition of the research gap that has to be overcome in the future.

This literature review is divided into several parts. In the first part, the review of researches of international experience within the theory of upper echelons is presented. The second part presents data collection and the method of literature classification. The third part is devoted to the interpretation of the research results. Finally, there are sections devoted to the discussion of the research results and the conclusion.

\section{International experience in upper echelon theory}

The theory of upper echelons postulates how the characteristics of top managers are of crucial importance to the management of the company (Hambrick and Mason, 1984). The theory attempts to explain the role of managerial characteristics in company management, through limited rationality, conflict of multiple goals, different levels of aspiration. It was founded on the behavioural theory of business (Cyert and March, 1955, Hambrick and Mason, 1984).

In the same period, over the last few decades, expansive internationalization all over the globe has emerged. Johanson and Wiedersheim-Paul (1975) defined internationalization as: "The attitude of the company towards foreign activities or a company that undertakes activities abroad", which has nowadays serious impact on organizations. Consequently, internationalization is considered increasingly important for many companies (Rajagopalan and Spreitzer, 1997). Literature about internationalization highlights a number of advantages for the companies: the possibility of economies of scale (Kogut, 1985), dispersion of market risk, the capacity to achieve cheaper components for production and others (Gomes and Ramaswamy, 1999). Therefore, it has become of great importance for companies which allows them to operate steadily in the long run (Bartlett and Ghoshal, 1998).

International experience of managers is often related to reducing the risk of international affairs (Sambharya, 1996) and it helps managers to run business in other countries. It also has implications for foreign market entry, making it less difficult and less risky. Due to the variety of target foreign markets, a company is faced with different characteristics of demand and a greater spectrum of international actors (Barkema and Vermeulen, 1998). Additionally, moving the barrier of "foreign" and integrating what the manager has learned about a foreign market at his own, has profound impact on his psychological characteristics. Top managers with vast knowledge of foreign cultures possess a unique set of skills that give them greater confidence in managing foreign markets (Hermann and Datta, 2005). CEOs coming from other countries and taking over the position of an existing CEO will naturally be inclined for internationalization of the company (Lin and Liu, 2012). Also, CEOs of SMEs with international experience positively influence the international involvement of their companies (Hsu et al., 2013). There is a research linking the demographic characteristics of the CEO and the strategy of entering the foreign markets with SME's (Laufs et al., 2016).

Teams of top managers who are diverse will more easily recognize the opportunities for overseas expansion through scanning of the foreign environment. Those kinds of managers will use all of their knowledge and business contacts before 
entering the new markets. Information of that importance is valuable resources for decision making in the process of internationalization (Nielsen, 2010).

\section{Methodology}

In order to select relevant research in the field of internationalization and upper echelon, we searched the Web of Knowledge. As a database search criteria, we used "upper echelon" and "international experience" phrases to get a list of papers that match the criteria. These terms were searched both in the title and in the topic of the paper. We used the lexeme '*' to get other possible combination of upper echelon words like "upper echelons". Following this approach we received an initial list of 45 papers, after which we retained only those papers that are related to "business", "management" or "economic" topics excluding sociology, psychology and other categories. Also, we excluded all types of document types except for research papers published in journals and as book chapters. At the end of the filtration process we got a list of 38 papers that match our search in the period from 1984 (when upper echelon theory was established) to 2016 (listed in Appendix).

\section{Results}

The upper echelon theory has been presented in 1984 by Hambrick and Mason (1984) and since then it has been the subject of many research papers. One of the foundations of this theory is demographic characteristics of managers. Sometimes are managers individually like CEOs, and sometimes is the entire team of top managers in the focus of research. However, irrespective of the reporting unit, the demographic characteristics such as ethnicity, gender, age, functional experience and other, were mostly the subject of research. It is important to emphasize that international experience as a demographic variable is dynamic, i.e. it is not present in every manager and it is developing over time.

As a time constraint we took a period from 1984 when the theory was created until 2016, including December. As shown in Figure 1 from 2009 there is a noticeable increase in the number of published papers. Also, since 2010 there is also noticeable jump in the number of citations of these papers within one year (Figure 2). In order to put the area of international experience in the theory of upper echelons into a wider context, Figure 3 shows the number of published papers and Figure 4 the number of citations in the field of upper echelon theory.

It is clear that there has been a significant increase in the number of papers and citations since 2009 in the field of upper echelon theory as well as international experience. During ten years there have been 1 to 2 papers in the field of international experience within the theory of upper echelons while in 2010 that number was 6 and has been steadily maintained all the way till 2016.

Potential reasons for growing interest in this area of research can be found above all in globalization. Encouraged by the crisis in 2008 and the fall of the real economy in almost all parts of the United States, the European Union and the rest of the world, companies had to find stable income and divergence of foreign business risk. As top management team needs to be exceptional to run the business so have internationalization and international experience become the focus of researchers around the world. All this led to intensifying the research of managers' influence on organizational processes, primarily their demographic characteristics such as ethnicity, age, gender, experience, and subsequently international experience. 
Figure 1 Published papers per year in the area of internationalization and upper echelon theory

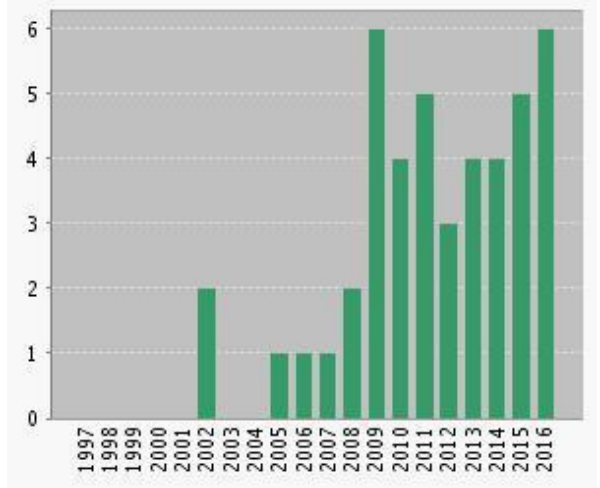

Figure 2 Number of citations per year of papers presented in Figure 1

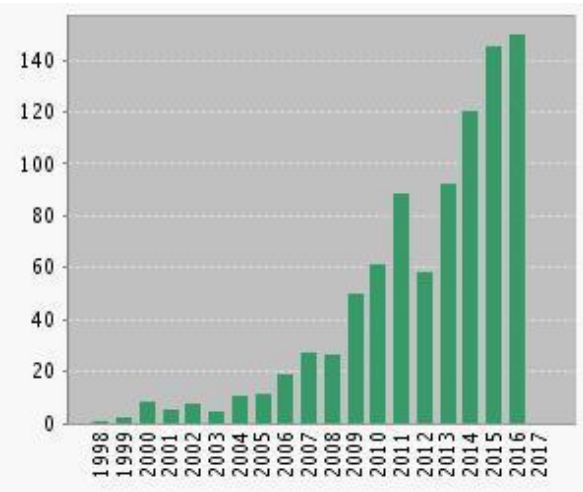

Source: Web of Science (consulted on 12 December 2016)

Figure 3 Published papers per year

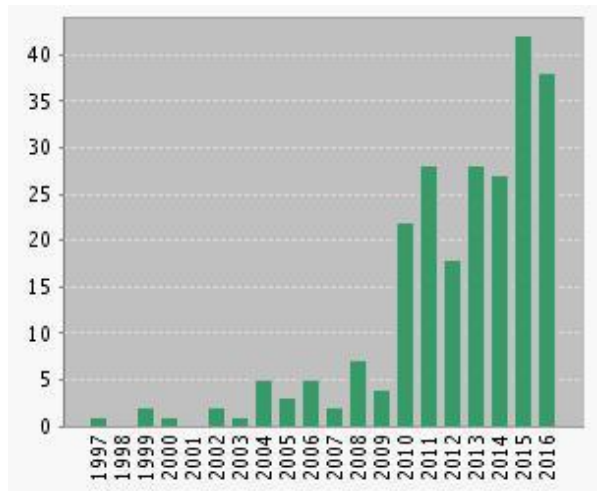

Figure 4 Number of citations per year

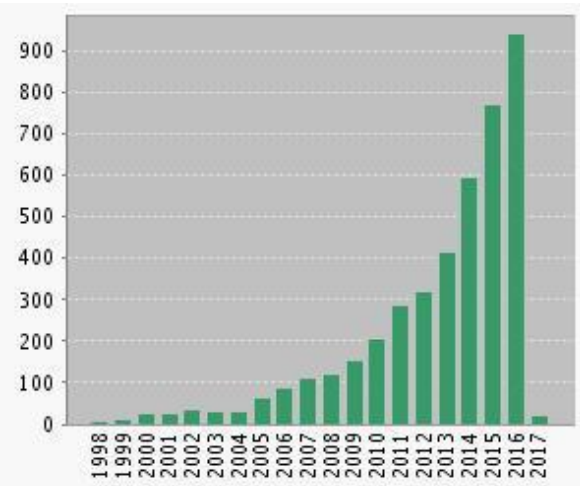

Source: Web of Science (consulted on 12 December 2016)

In Table 1 we can see a breakdown by authors' countries. As it is shown, approximately $50 \%$ of papers are written in non-English speaking countries such as Germany, Switzerland, Taiwan, Denmark, South Korea, China, India and others while the other $50 \%$ of papers are written by authors from English-speaking areas such as USA, England and Australia.

Table 1

Breakdown of Papers by Author's Country (top 5)

\begin{tabular}{lcc}
\hline Countries/Territories & Records & $\%$ of $\mathbf{3 8}$ \\
\hline GERMANY & 12 & 31.58 \\
USA & 11 & 38.95 \\
SWITZERLAND & 4 & 10.53 \\
TAIWAN & 3 & 7.90 \\
DENMARK & 3 & 7.90
\end{tabular}

Source: Web of Science (consulted on 12 December 2016)

Table 1 indicates that European Union countries are among the most productive research areas of the international experience in the upper echelon theory and at the same time are those who issue the most papers which point to the possible universality of the theory, i.e. the influence of international experience of managers on different business segments of the company. To make the theory more plausible it 
is necessary to increase the number of researches in the coming years from different countries but also at different organizational levels.

In regards to the main journals in which the papers related to the area of international experience within the upper echelon theory are published (Table 2.), we can see that $36,85 \%$ of all papers about that topic in the observed period were published in three journals.

Previous research use Herfindahl Hirschamn's HHI concentration index for analysis of concentration of research journals (e.g. Dabic et al., 2015). According to Herfindahl Hirschamn's HHI concentration index, we can conclude that this field has a small concentration ( $\mathrm{HHI}$ 687) because this index ranges from 0 to 10,000 (in case one journal describes the entire area) while 0 is the value that tends to the indefinite number of journals. Although this index is used to calculate market concentration, it is widely used in bibliometric analysis literature.

Unlike the Herfindahl Hirschman's index, the Fidessa Fragmentation Index (FFI) is calculated as an inversion of the Hirschman's H-index. We wanted to know how the journals are fragmented in the international experience topic, so FFI can provide us with this information. This index has a history of analysis in sectors like finance, where it was used to calculate fragmentation of stocks across the market, for example, as shown by Pierron (2010) and Axioglou and Skouras (2011). Since it is an inversion of the Hirschman index it can vary from 1 to 38 papers because there are only 38 papers that address the international experience topic. According to the above stated authors, this index provides the number of papers dealing exclusively with this topic. In our case the FFI is 3.73, which means that most of the papers are concentrated in four journals. As shown in Table 2, nearly $36 \%$ of all papers are written in the first three journals or $42 \%$ if we include the fourth journal.

Table 2

Top 5 Journals Publishing Papers Related to Upper Echelons and International Experience

\begin{tabular}{lcc}
\hline SOUICE: Titles & Records & $\%$ of $\mathbf{3 8}$ \\
\hline JOURNAL OF WORDL BUSINESS & 6 & 15.79 \\
MANAGEMENT INTERNATIONAL REVIEW & 4 & 10.53 \\
BRITISH JOURNAL OF MANAGEMENT & 4 & 10.53 \\
STRATEGIC MANAGEMENT JOURNAL & 2 & 5.26 \\
HANDBOOK OF RESEARCH ON TOP MANAGENT TEAMS & 2 & 5.26 \\
\hline
\end{tabular}

Source: Web of Science (consulted on 12 December 2016)

Based on presented results we can say that this area is still very young and represented in a small number of journals. A large number of papers are published in only one journal so an increase of number of papers in different journals can be expected, as the research area will expand.

According to Table 3, the top five authors wrote 8 different papers, representing $21.05 \%$ of the total number of analyzed papers (38). The top five authors represent a total of 625 citations, which is more than $72 \%$ of the total number of citations (861) that we have collected and analyzed over a period of time from 1985 to 2016. If we consider the frequency of the author's citation, as can be seen in column (a) of Table 3, the three most cited authors are Carpenter (176 citations, $20.44 \%$ of the total number of citations), Sambharya (163 citations, $18.93 \%$ of total number) and Herrmann (144 citations, $16.72 \%$ of the total number of citations).

However, if we take the most productive authors in the classification (see Table 3 , column (d) under the number of papers), the top three authors are Nielsen (3 
papers), Herrmann (2 papers) and the rest of the authors each 1, among them listed as top three in alphabetical order - Carpenter (1 paper).

Table 3

Top 5 Most Cited Authors

\begin{tabular}{lccccc}
\hline Author & $\begin{array}{c}\text { a) } \\
\text { Frequency } \\
\text { of author } \\
\text { citations }\end{array}$ & $\begin{array}{c}\text { Frequency of } \\
\text { author } \\
\text { citations } \\
(\mathbf{n = 8 6 1 )}\end{array}$ & $\begin{array}{c}\text { c) } \\
\text { Average } \\
\text { citations per } \\
\text { paper }\end{array}$ & $\begin{array}{c}\text { d) } \\
\text { Number of } \\
\text { author's } \\
\text { papers }\end{array}$ & $\begin{array}{c}\text { Percentage of } \\
\text { author's } \\
\text { papers (n=38) }\end{array}$ \\
\hline Carpenter, M.A. & 176 & 20.44 & 176 & 1 & 2.63 \\
Sambharya, R.B. & 163 & 18.93 & 163 & 1 & 2.63 \\
Hermann, P. & 144 & 16.72 & 72 & 2 & 5.26 \\
Nielsen, S. & 93 & 8.94 & 31 & 3 & 7.89 \\
Ruzzier, M. & 49 & 5.69 & 49 & 1 & 2.63 \\
\hline
\end{tabular}

Source: Web of Science (consulted on 12 December 2016)

If we look at column (c) and take into consideration the number of citations per published papers, top three authors are still the same. These are Carpenter (176 citations on average, 1 paper), Sambhary (163 citations on average, 1 paper), and Herrmann (72 citations on average, 2 papers). Based on the analysis of the citations and the number of papers published by the authors, we can conclude that the first three authors have paved the path for all the others to come. Also, based on everything said we can conclude that the area is still very young and that new authors like Nielsen and Ruzzier are coming, which further deepen the theory and whose topicality will grow.

Table 4 show the top 5 most popular papers published in the period from 1985 to 2016. The years we have taken into consideration are from 2012 to 2016 and we have analyzed the number of citations per paper. The average number of citations per year for all the mentioned papers is 45.32 .

Table 4

Top 5 Most Cited Papers in the Period 1955. - 2016.

\begin{tabular}{|c|c|c|c|c|c|c|c|}
\hline Author & $\begin{array}{c}\text { Total citations } \\
1955 \text { - } 2016\end{array}$ & $\begin{array}{c}\text { Average } \\
\text { citations per } \\
\text { year }\end{array}$ & 2012 & 2013 & 2014 & 2015 & 2016 \\
\hline $\begin{array}{l}\text { Total number of } \\
\text { papers }\end{array}$ & 861 & 45.32 & 58 & 88 & 112 & 132 & 150 \\
\hline Carpenter (2002) & 176 & 11.00 & 11 & 19 & 17 & 22 & 19 \\
\hline Sambharya (1996) & 163 & 7.41 & 9 & 14 & 12 & 13 & 13 \\
\hline $\begin{array}{l}\text { Herrmann and } \\
\text { Datta (2002) }\end{array}$ & 77 & 4.81 & 4 & 4 & 7 & 10 & 10 \\
\hline $\begin{array}{l}\text { Herrmann and } \\
\text { Datta (2005) }\end{array}$ & 67 & 5.15 & 3 & 6 & 6 & 8 & 8 \\
\hline $\begin{array}{l}\text { Nielsen and } \\
\text { Nielsen (2011) }\end{array}$ & 53 & 7.57 & 2 & 8 & 12 & 12 & 17 \\
\hline
\end{tabular}

Source: Web of Science (consulted on 12 December 2016)

As in the tables before, the first three papers are works of the same authors. Namely, the first three papers hold almost $50 \%$ of the total number of citations. As mentioned above, the top five papers refer to the influence of the heterogeneity of demographic characteristics, including international experience, on some sort of 
organizational performance in accordance with the Hambrick and Mason (1984) theories. However, in order for the review to be complete in the next paragraphs, we will devote our attention to the analysis of the topics of all 38 papers in the next section.

\section{Discussion}

The main aim of this paper was to undertake a thorough analysis of the literature on the international experience of top managers within the upper echelon theory and to summarize research of over twenty years. Content analysis was made based on 38 papers that dealt with the above mentioned area. The research area was defined with 38 papers and 76 keywords used in the titles. This literature review has the task of combining all the researches carried out on international experience in upper echelon theory and providing insights into potential new directions of research. Also, the meaning of this literature review is to point to the potential deficiencies of the theory that would lead to the realization of its universality.

International experience as a demographic characteristic within the theory of upper echelons was first seen in the work of Sambharya (1996). It is also the base year when research of this area begins. Subsequently, Carpenter publishes significant works in 2002, which further deepen the upper echelon theory with an international perspective. The overall list of the selected research according to the time development is presented in Table 6.

\section{Table 6}

The summarized results of systematic literature review of selected papers

\begin{tabular}{|c|c|c|c|}
\hline $\begin{array}{l}\text { Author(s), year } \\
\text { of publication }\end{array}$ & $\begin{array}{l}\text { Target country } \\
\text { of study }\end{array}$ & Industry & Research objective(s) \\
\hline $\begin{array}{l}\text { Sambharya, } \\
1996\end{array}$ & USA & Fortune 500 & $\begin{array}{l}\text { Relationship between TMT international } \\
\text { experience and international diversification }\end{array}$ \\
\hline Carpenter, 2002 & USA & $\begin{array}{l}\text { Standard \& } \\
\text { Poors (S\&P) } \\
\text { industrial } \\
\text { index }\end{array}$ & TMT heterogeneity and firm performance \\
\hline $\begin{array}{l}\text { Herrmann and } \\
\text { Datta, } 2002\end{array}$ & USA & $\begin{array}{l}\text { Manufacturi } \\
\text { ng industries }\end{array}$ & $\begin{array}{l}\text { Examines relationship between CEO } \\
\text { successor characteristics and foreign market } \\
\text { entry mode }\end{array}$ \\
\hline $\begin{array}{l}\text { Herrmann and } \\
\text { Datta, } 2005\end{array}$ & USA & $\begin{array}{l}\text { manufacturi } \\
\text { ng sector }\end{array}$ & $\begin{array}{l}\text { Relationship between TMT demographic } \\
\text { characteristics and international } \\
\text { diversification }\end{array}$ \\
\hline $\begin{array}{l}\text { Lee and Park, } \\
2006\end{array}$ & USA & $\begin{array}{l}\text { Aerospace, } \\
\text { computer } \\
\text { equipment, } \\
\text { food, etc. }\end{array}$ & $\begin{array}{l}\text { Linkage between TMT demographic } \\
\text { characteristics, based on upper echelon } \\
\text { theory, and firm internationalization }\end{array}$ \\
\hline $\begin{array}{l}\text { Ruzzier et al., } \\
2007\end{array}$ & Slovenia & IPIS Slovenia & $\begin{array}{l}\text { Impact of human capital on SMEs } \\
\text { internationalization }\end{array}$ \\
\hline $\begin{array}{l}\text { Lee and Park, } \\
2008\end{array}$ & USA & $\begin{array}{l}\text { Stock } \\
\text { exchange } \\
\text { firms }\end{array}$ & $\begin{array}{l}\text { Influence of TMT international experience } \\
\text { and international alliances }\end{array}$ \\
\hline $\begin{array}{l}\text { Patzelt, H., et al., } \\
2009\end{array}$ & Europe & $\begin{array}{l}\text { European } \\
\text { Venture } \\
\text { Capital firms }\end{array}$ & $\begin{array}{l}\text { Impact of TMT composition on portfolio } \\
\text { strategy choice }\end{array}$ \\
\hline $\begin{array}{l}\text { Greve et al., } \\
2009\end{array}$ & Europe & $\begin{array}{l}\text { Banking and } \\
\text { insurance }\end{array}$ & $\begin{array}{l}\text { Relationship between TMT configuration and } \\
\text { DOI }\end{array}$ \\
\hline
\end{tabular}




\begin{tabular}{|c|c|c|c|}
\hline $\begin{array}{l}\text { Author(s), year } \\
\text { of publication }\end{array}$ & $\begin{array}{l}\text { Target country } \\
\text { of study }\end{array}$ & Industry & Research objective(s) \\
\hline $\begin{array}{l}\text { Biemann and } \\
\text { Wolf, } 2009\end{array}$ & $\begin{array}{l}\text { EU, Japan, UK } \\
\text { and the United } \\
\text { States }\end{array}$ & $\mathrm{N} / \mathrm{A}$ & $\begin{array}{l}\text { Analyzes career paths of TMTs based on their } \\
\text { international experience }\end{array}$ \\
\hline $\begin{array}{l}\text { Slater and } \\
\text { Dixon-Fowler, } \\
2009\end{array}$ & USA & S\&P 500 & $\begin{array}{l}\text { Analyzes if CEO international experience } \\
\text { influence corporative social performance }\end{array}$ \\
\hline Nielsen, 2010 & Switzerland & $\begin{array}{l}\text { Stock } \\
\text { exchange } \\
\text { firms }\end{array}$ & $\begin{array}{l}\text { Relationship between TMT international } \\
\text { characteristics and foreign operations ability }\end{array}$ \\
\hline $\begin{array}{l}\text { Nielsen and } \\
\text { Nielsen, } 2011\end{array}$ & Switzerland & $\begin{array}{l}\text { Stock } \\
\text { exchange } \\
\text { firms }\end{array}$ & $\begin{array}{l}\text { This study is concentrated on link between } \\
\text { managers characteristics and foreign entry } \\
\text { mode }\end{array}$ \\
\hline Chen, 2011 & Taiwan & $\begin{array}{l}\text { TSEC and GTSM } \\
\text { listed firms }\end{array}$ & $\begin{array}{l}\text { This paper examines the effects of TMT } \\
\text { characteristics on internationalization and } \\
\text { the moderating effect of independent } \\
\text { directors on the TMT characteristics - } \\
\text { internationalization relationship }\end{array}$ \\
\hline Kirca et al., 2012 & N/A & N/A & $\begin{array}{l}\text { Research which multilevel characteristics } \\
\text { impact firms multinationality the most }\end{array}$ \\
\hline Lin and Liu, 2012 & Taiwan & $\begin{array}{l}\text { Stock exchange } \\
\text { firms }\end{array}$ & $\begin{array}{l}\text { Relationship between characteristics of } \\
\text { successor, DOI and performance }\end{array}$ \\
\hline Rivas, 2012 & $\begin{array}{l}\text { Europe and } \\
\text { USA }\end{array}$ & $\begin{array}{l}\text { Stock exchange } \\
\text { firms }\end{array}$ & $\begin{array}{l}\text { Relationship between TMT international } \\
\text { experience, CEO characteristics and DOI }\end{array}$ \\
\hline Hsu et al., 2013 & Taiwan & $\begin{array}{l}\text { TSEC and GTSM } \\
\text { listed SME's }\end{array}$ & $\begin{array}{l}\text { Impact of CEO characteristics on } \\
\text { performance of internationalization in SME's }\end{array}$ \\
\hline $\begin{array}{l}\text { Hutzschenreute, } \\
\text { and Horstkotte, } \\
2013\end{array}$ & Germany & $\begin{array}{l}\text { German stock } \\
\text { exchange }\end{array}$ & $\begin{array}{l}\text { Influence of TMT experience on } \\
\text { performance, effect of added cultural } \\
\text { distance in international expansion process }\end{array}$ \\
\hline $\begin{array}{l}\text { Kaczmarek and } \\
\text { Ruigrok, } 2013\end{array}$ & $\begin{array}{l}\text { Dutch, } \\
\text { Swiss, and } \\
\text { UK } \\
\text { companies }\end{array}$ & $\begin{array}{l}\text { Stock exchange } \\
\text { firms }\end{array}$ & $\begin{array}{l}\text { Examines TMT national diversity and firms } \\
\text { internationalization }\end{array}$ \\
\hline $\begin{array}{l}\text { Piaskowska and } \\
\text { Trojanowski, } \\
2014\end{array}$ & UK & $\begin{array}{l}\text { Stock exchange } \\
\text { firms }\end{array}$ & $\begin{array}{l}\text { Examines strategic decision-making of TMTs } \\
\text { and how those decisions influence } \\
\text { internationalization }\end{array}$ \\
\hline $\begin{array}{l}\text { Schmid and } \\
\text { Dauth, } 2014\end{array}$ & Germany & $\begin{array}{l}\text { Stock exchange } \\
\text { firms }\end{array}$ & $\begin{array}{l}\text { Examines link between international } \\
\text { experience of CEO and stock market }\end{array}$ \\
\hline $\begin{array}{l}\text { Chittoor et al., } \\
2015\end{array}$ & India & BSE 500 & $\begin{array}{l}\text { Link between foreign market entry of Indian } \\
\text { companies and ownership characteristics }\end{array}$ \\
\hline $\begin{array}{l}\text { Agnihotri and } \\
\text { Bhattachary, } \\
2015\end{array}$ & India & $\begin{array}{l}\text { Consumer goods, } \\
\text { automobiles etc. }\end{array}$ & $\begin{array}{l}\text { Relationship between international } \\
\text { experiences and export intensity }\end{array}$ \\
\hline $\begin{array}{l}\text { Dauth and } \\
\text { Tomczak, } 2016\end{array}$ & Poland & $\begin{array}{l}\text { Stock exchange } \\
\text { firms }\end{array}$ & $\begin{array}{l}\text { Impact of upper echelons internationalization } \\
\text { on firms internationalization }\end{array}$ \\
\hline Laufs et al., 2016 & Germany & $\begin{array}{l}\text { German } \\
\text { SMEs }\end{array}$ & $\begin{array}{l}\text { Impact of CEO characteristics and SMEs } \\
\text { foreign market entry mode }\end{array}$ \\
\hline $\begin{array}{l}\text { Georgakakis et } \\
\text { al., } 2016\end{array}$ & $\begin{array}{l}\text { Switzerland, } \\
\text { the } \\
\text { Netherlands, } \\
\text { Germany } \\
\text { and the UK }\end{array}$ & $\begin{array}{l}\text { Stock } \\
\text { exchange firms }\end{array}$ & $\begin{array}{l}\text { Impact of international experience on career } \\
\text { advancement }\end{array}$ \\
\hline $\begin{array}{l}\text { Schmid and } \\
\text { Wurster, } 2016\end{array}$ & Germany & $\begin{array}{l}\text { Stock } \\
\text { exchange firms }\end{array}$ & $\begin{array}{l}\text { Examines hypothesis that international } \\
\text { experience of TMT influence pay level }\end{array}$ \\
\hline
\end{tabular}

Source: Author's work 


\section{International experience and degree of internationalization}

There are several studies that are focusing on the impact of international experience on the degree or model of internationalization. Agnihotri and Bhattacharya (2015) point out that the international experience of managers positively affects the export intensity of Indian companies. In addition, Taiwanese companies gain more levels of internationalization when their managers have more international and work experience (Chen, 2011).

International experience is also important at distinct levels, either individually in the form of a CEO or as a group in the form of top management team. In both cases it has a positive influence on the level of internationalization (Rivas, 2012). Therefore, research based on the study of demographic characteristics such as years, experience, education, career development and their impact on internationalization of business are no longer sufficient. In today's globalized world, it is necessary to add international experience to these characteristics. Although there is not much research in the field of upper echelon theory, it is likely that this will change in the future.

International experience also has an important predictive purpose. It can be the predecessor of larger international involvement in top managers who run small and medium-sized companies (Ruzzier et al., 2007).

It is to be expected that teams of top managers with international experience will lead to higher degrees of international involvement due to their superior ability to grasp more complex information and to organize various strategies that precede the entry into the foreign market. Empirical evidence suggests a positive link in this area. Some of them include the degree of internationalization (Lee and Park 2006, Sambharya 1996), degree of international diversification (Herrmann and Datta, 2005) and changes in the international diversification (Wally and Becerra, 2001). Some research even points out that the international experience of a team of top managers as well as national diversity can be the answer to the international strategies (Nielsen and Nielsen 2009; Greve et al., 2009).

\section{International experience and strategic choices}

Faced with increasing competition, companies perceive the need for managers who have the attributes and a set of skills for successful management in increasingly complex international conditions (Hermann and Datta, 2005). Based on the theory of upper echelon, most of the available studies stress out the importance of demographic characteristics of managers as true assessors of their cognitive orientations, values and knowledge, thus influencing the strategic choices (Hermann and Datta, 2005). Education, functional career and international experience on international alliances and models of internationalization also have an important impact (Lee and Park, 2006, 2008), as well as demographic characteristics on strategic choices (Michailova, 2011).

\section{International experience and foreign market entry}

Researchers like Bartlett and Ghosal (1989) and others highlight the importance of managers to understand and conduct foreign business. Kobrin (1984) points out that the manager's knowledge about the foreign market operation and their institution eases the decision-making. Understanding how top management knowledge affects internationalization is important for scientists and top managers as well (Hermann and Datta, 2005). First of all, entry into a foreign market is accompanied by a high level of uncertainty and risk. Depending on the market entry model - fully controlled (acquisitions and Greenfield investments) or partially controlled - depends 
also on the knowledge that the top manager possesses. For example, a top manager with significant international experience in entering the foreign market will use the acquisition strategy (Chittoor et al., 2015) and the model of complete control (Herrmann and Datta, 2002). Some research suggests that companies from the banking and insurance sectors, when entering a foreign market, will look for managers with international experience close to their strategies (Greve et al., 2009). Others emphasize that international experience will reduce the cultural distance and increase the profitability of companies on foreign markets (Hutzschenreuter and Horstkotte, 2013). Nielsen (2010) emphasizes that international experience will moderate the uncertainty and risk of entering a foreign market, will shape its awareness and the way of processing information that will influence decision-making about the choice of strategy (Nielsen and Nielsen, 2011; Piaskowska and Trojanowski, 2014).

\section{Additional benefits of international experience}

The experience that top managers gain from working on foreign markets is considered a highly valuable resource for a company that enhances its competitive advantage. Athanassiou and Nigh (2002) points out that international experience is excellent for different sources of information. International experience also affects the salary of the manager. More international experience leads to higher wages, but with some degree of uncertainty, due to the recent data included in the research (Schmid and Wurster, 2016).

\section{International experience and firm performance}

By entering the foreign market, the advantages of international experience are likely to be transmitted to corporate results. One of the first researches which demonstrates how nationally heterogeneous teams of top managers are better at managing foreign branches and as evidence provide better business performance for subsidiaries was conducted by Elron (1997). However, there is not much research that investigates the direct links between the internationalization, international experience and business performance. Namely, Carpenter (2002) has linked the positive influence of internationalization to the performance of companies but only with the high degree of internationalization. On the other hand, Wang et al. (2015) points out that hiring managers with international IT experience has a positive impact on both short-term and long-term performance as well as on innovation and operations in overseas countries. Similarly, Nielsen (2010) argues that at highly internationalized organizations, senior managers foster better organizational. However, there are also researches that have not revealed such positive relationships (Dauth and Tomczak, 2016). Therefore, intensifying research of direct impact of business operations should be the focus of future research.

Researchers have over the last twenty years supplemented this gap that has emerged in the literature, but today there is another evident void. The existing literature in the theory of upper echelon, which is facing toward the international context, e.g. (Nielsen, 2010, Lee and Park, 2006, Slater and Dixon-Fowler, 2009, Ruzzier et al., 2007), is mostly based on North American multinational companies.

The overall focus of research is directed at multinational companies, which is logical, given the number of international strategies they undertake. If we want to address problem of international experience within small and medium-sized companies, only two studies are devoted to it (Hsu et al., 2013; Ruzzier et al., 2007). Given that the SME's are playing important role in the economy of the European Union, we think this is a topic that needs to be given more attention. 


\section{Conclusion}

The paper presents the literature review in the field of international experience of top managers related to the upper echelon theory. We selected 38 research papers in the field from the Web of Knowledge database. Based on the time distribution of the papers, we conclude that the area of research is emerging and it needs to be further explored in different research directions. First, changing the focus from multinational companies to small and medium businesses would significantly improve the theory and contribute to its strength. Second, the influence of the managers' nationality and culture from which they come on the international experience is one of the possible directions of research. Third, the theory has the possibility of uniformity; however, as stated at the beginning, it is necessary to increase the number of researches from other countries.

The question of international experience is the question of knowledge. In today's highly globalized world, knowledge of internationalization strategies is a very valuable resource. If one possesses the knowledge the "psychological" boundaries (Johanson and Vhalne, 1977) in business are reduced. Customs and traditions that were distant and unknown are now close and familiar. Also, as Sambharya (1996) mentions a company recruiting managers with international experience has triple benefits. It serves as a variable to reduce international business uncertainty; (b) it is used as a source of knowledge about a foreign culture (c) international experience is the answer of the company to the growing challenges of market globalization.

Hence, recruiting managers with international experience must be in the focus of companies that have a more international presence in their strategy. They can provide greater speed and quality of the internationalization process. Particularly at a time when there is a great deal of pressure on management and return on investment, especially in the stages of stagnation and recession (Dabic et al., 2015).

The more research-based on small and medium-sized companies is needed, since the deficit of such research is strikingly obvious. This thought is on the trail of Schmid and Wurster (2015) research who have studied the differences of international experience of top managers from Germany and Great Britain. This research concluded that there are significant differences between the two countries. Therefore, as Dabic et al. (2015) pointed out a broader geographic perspective in empirical research is needed to confirm the universality of the theory of international experience in the theory of upper echelon or to determine its affiliation to contextual legality of the size of the organization. Practical implications of this research are primarily directed at managers and business owners. Research revealed that the international experience significantly contributes to the expansion of perception, better resonance, easier and safer management of complex international affairs, and other factors. In addition, international experience, have also significant implications for managers in terms of higher earnings and faster career advancement, as some of the research has shown.

However, when taking into account the results of the research several limitations emerge. First, a large number of researches focus on multinational companies which may indicate that the aforementioned theory is not applicable to small and medium-sized companies. Second, almost all of the research comes from economically developed countries which may indicate that the theory is not applicable to less developed countries. Third, it is necessary to increase the number of researches from different countries to determine whether there is a possibility of unifying the theory. These also represent the fruitful promising topics of future research in the area of internationalization and upper echelon theory. 


\section{References}

1. Agnihotri, A., Bhattacharya, S. (2015), "Determinants of export intensity in emerging markets: An upper echelon perspective", Journal of World Business, Vol. 50, No. 4, pp. 687-695.

2. Athanassiou, N., Nigh, D. (2002), "The Impact of the Top Management Team's International Business Experience on the Firm's Internationalization: Social Networks at Work", MIR: Management International Review, Vol. 42, No. 2, pp. 157-181.

3. Axioglou, C., Skouras, S. (2011), "Markets Change Every Day: Evidence from the Memory of Trade Direction", Journal of Empirical Finance, Vol. 18, No. 3, pp. 423446.

4. Barkema, H. G., Vermeulen, F. (1998), "International expansion through start-up or acquisition: A learning perspective", Academy of Management Journal, Vol. 41, No. 1, pp. 7-26.

5. Bartlett, C. A., Ghoshal, S. (1998), "Beyond strategic planning to organization learning: Lifeblood of the individualized company", Strategy \& Leadership, Vol. 26, No. 1, pp. 34-39.

6. Biemann, T., Wolf, J. (2009), "Career patterns of top management team members in five countries: an optimal matching analysis", International Journal of Human Resource Management, Vol. 20, No. 5, pp. 975-991.

7. Carpenter, M. A. (2002), "The implications of strategy and social context for the relationship between top management team heterogeneity and firm performance", Strategic Management Journal, Vol. 23, No. 3, pp. 275-284.

8. Chen, H. L. (2011), "Does Board Independence Influence the Top Management Team? Evidence from Strategic Decisions toward Internationalization", Corporate Governance: An International Review, Vol. 19, No. 4, pp. 334-350.

9. Chittoor, R., Aulakh, P. S., Ray, S. (2015), "What drives overseas acquisitions by Indian firms? A behavioral risk-taking perspective", Management International Review, Vol. 55, No. 2, pp. 255-275.

10. Cyert, R. M., March, J. G. (1955), "Organizational structure and pricing behavior in an oligopolistic market", The American Economic Review, Vol. 45, No. 1, pp. 129139.

11. Dabic, M., González-Loureiro, M., Harvey, M. (2015), "Evolving research on expatriates: what is 'known'after four decades (1970-2012)", The International Journal of Human Resource Management, Vol. 26, No. 3, pp. 316-337.

12. Dauth, T., Tomczak, A. (2016), "Internationalization of top management teams: A comprehensive analysis of Polish stock-listed firms", Journal for East European Management Studies, Vol. 21, No. 2, pp. 167-183.

13. Elron, E., (1997), "Top management teams within multinational companies: Effects of cultural heterogeneity", The Leadership Quarterly, Vol. 8, No. 4, pp. 393-412.

14. Georgakakis, D., Dauth, T., Ruigrok, W. (2016), "Too much of a good thing: Does international experience variety accelerate or delay executives' career advancement?", Journal of World Business, Vol. 51, No. 3, pp. 425-437.

15. Gomes, L., Ramaswamy, K. (1999), "An empirical examination of the form of the relationship between multinationality and performance", Journal of international business studies, Vol. 30, No. 1, pp. 173-187.

16. Greve, P., Nielsen, S., Ruigrok, W. (2009), "Transcending borders with international top management teams: A study of European financial multinational companies", European Management Journal, Vol. 27, No. 3, pp. 213-224. 
17. Hambrick, D. C., Mason, P. A. (1984), "Upper echelons: The organization as a reflection of its top managers", Academy of Management Review, Vol. 9, No. 2, pp. 193-206.

18. Herrmann, P., Datta, D. K. (2002), "CEO successor characteristics and the choice of foreign market entry mode: An empirical study", Journal of International Business Studies, Vol. 33, No. 3, pp. 551-569.

19. Herrmann, P., Datta, D. K. (2005), "Relationships between top management team characteristics and international diversification: An empirical investigation", British Journal of Management, Vol. 16, No. 1, pp. 69-78.

20. Hsu, W. T., Chen, H. L., Cheng, C. Y. (2013), "Internationalization and firm performance of SMEs: The moderating effects of CEO attributes", Journal of World Business, Vol. 48, No. 1, pp. 1-12.

21. Hutzschenreuter, T., Horstkotte, J. (2013), "Performance effects of international expansion processes: The moderating role of top management team experiences", International Business Review, Vol. 22, No. 1, pp. 259-277.

22. Johanson, J., Vahlne, J. (1977), "The Internationalization Process of the Firm-A Model of Knowledge Development and Increasing Foreign Market Commitments", Journal of International Business Studies, Vol. 8, No. 1, pp. 23-32.

23. Johanson, J., Wiedersheim-Paul, F. (1975), "The internationalization of the firmfour Swedish cases", Journal of management studies, Vol. 12, No. 3, pp. 305-323.

24. Kaczmarek, S., Ruigrok, W. (2013), "In at the Deep End of Firm Internationalization", Management International Review, Vol. 53, No. 4, pp. 513-534.

25. Kirca, A. H., Hult, G. T. M., Deligonul, S., Perryy, M. Z., Cavusgil, S. T. (2012), "A multilevel examination of the drivers of firm multinationality: A meta-analysis", Journal of Management, Vol. 38, No. 2, pp. 502-530.

26. Kobrin, S. J. (1984), "Expropriation as an attempt to control foreign firms in LDCs: trends from 1960 to 1979", International Studies Quarterly, Vol. 28, No. 3, pp. 329348.

27. Kogut, B. (1985), "Designing global strategies: Comparative and competitive value-added chains", Sloan management review, Vol. 26, No. 4, pp. 15-28.

28. Laufs, K., Bembom, M., Schwens, C. (2016), "CEO characteristics \& SME foreign market entry mode choice: The moderating effect of firm's geographic experience and host-country political risk", International Marketing Review, Vol. 33, No. 2, pp. 246-275.

29. Lee, H. U., Park, J. H. (2006), "Top team diversity, internationalization and the mediating effect of international alliances", British Journal of Management, Vol. 17, No. 3, pp. 195-213.

30. Lee, H. U., Park, J. H. (2008), "The influence of top management team international exposure on international alliance formation", Journal of Management Studies, Vol. 45, No. 5, pp. 961-981.

31. Lin, W. T., Liu, Y. S. (2012), "Successor characteristics, change in the degree of firm internationalization, and firm performance: The moderating role of environmental uncertainty", Journal of Management \& Organization, Vol. 18, No. 1, pp. 16-35.

32. Michailova, S. (2011), "Contextualizing in international business research: why do we need more of it and how can we be better at it?", Scandinavian Journal of Management, Vol. 27, No. 1, pp. 129-139.

33. Nielsen, B. B., Nielsen, S. (2009), "Learning and innovation in international strategic alliances: An empirical test of the role of trust and tacitness", Journal of Management Studies, Vol. 46, No. 6, pp. 1031-1056. 
34. Nielsen, B. B., Nielsen, S. (2011), "The role of top management team international orientation in international strategic decision-making: The choice of foreign entry mode", Journal of World Business, Vol. 46, No. 2, pp. 185-193.

35. Nielsen, S., (2010), "Top Management Team Internationalization and Firm Performance", Management International Review, Vol. 50, No. 2, pp. 185-206.

36. Patzelt, H., zu Knyphausen-Aufseß, D., Fischer, H. T. (2009), "Upper echelons and portfolio strategies of venture capital firms", Journal of Business Venturing, Vol. 24, No. 6, pp. 558-572.

37. Piaskowska, D., Trojanowski, G. (2014), "Twice as Smart? The Importance of Managers' Formative-Years' International Experience for their International Orientation and Foreign Acquisition Decisions", British Journal of Management, Vol. 25, No. 1, pp. 40-57.

38. Pierron, A. (2010), "Dark Pools: A Significant Element of the European Cash Equity Ecosystem", Trading, Vol. 2010, No. 1, pp. 101-107.

39. Rajagopalan, N., Spreitzer, G. M. (1997), "Toward a theory of strategic change: A multi-lens perspective and integrative framework", Academy of management review, Vol. 22, No. 1, pp. 48-79.

40. Rivas, J. L. (2012), "Board versus top management team international experience: a study of their joint effects", Cross Cultural Management: An International Journal, Vol. 19, No. 4, pp. 546-562.

41. Ruzzier, M., Antoncic, B., Hisrich, R. D., Konecnik, M. (2007), "Human capital and SME internationalization: A structural equation modeling study", Canadian Journal of Administrative Sciences/Revue Canadienne des Sciences de l'Administration, Vol. 24, No. 1, pp. 15-29.

42. Sambharya, R. B. (1996), "Foreign experience of top management teams and international diversification strategies of US multinational companies", Strategic Management Journal, Vol. 17, No. 9, pp. 739-746.

43. Schmid, S., Wurster, D. J. (2015), "Internationalisation of upper echelons in different institutional contexts: top managers in Germany and the UK", European Journal of International Management, Vol. 9, No. 4, pp. 510-535.

44. Schmid, S., Wurster, D. J. (2016) "Are international top executives paid more? Empirical evidence on fixed and variable compensation in management boards of German MNCs", European Journal of International Management, Vol. 10, No. 1, pp. 25-53.

45. Schmid, S., Dauth, T. (2014), "Does internationalization make a difference? Stock market reaction to announcements of international top executive appointments", Journal of World Business, Vol. 49, No. 1, pp. 63-77.

46. Slater, D. J., Dixon-Fowler, H. R. (2009), "CEO International Assignment Experience and Corporate Social Performance", Journal of Business Ethics, Vol. 89, No. 3, pp. 473-489.

47. Wally, S., Becerra, M. (2001), "Top management team characteristics and strategic changes in international diversification: the case of US multinationals in the European community", Group \& Organization Management, Vol. 26, No. 2, pp. 165-188.

48. Wang, X., Ma, L., Wang, Y. (2015), "The impact of top management team functional background on firm performance: Evidence from listed companies in China's IT industry", Nankai Business Review International, Vol. 6, No. 3, pp. 281311. 


\section{Appendix}

\section{List of reviewed papers}

1. Agnihotri, A., Bhattacharya, S. (2015), "Determinants of export intensity in emerging markets: An upper echelon perspective", Journal of World Business, Vol. 50, No. 4, pp. 687-695.

2. Benson, G. S., Pérez-Nordtvedt, L., Datta, D. K. (2009), „Managerial characteristics and willingness to send employees on expatriate assignments", Human Resource Management, Vol. 49, No. 6, pp. 849-869.

3. Biemann, T., Wolf, J. (2009), "Career patterns of top management team members in five countries: an optimal matching analysis", International Journal of Human Resource Management, Vol. 20, No. 5, pp. 975-991.

4. Carpenter, M. A. (2002), "The implications of strategy and social context for the relationship between top management team heterogeneity and firm performance", Strategic Management Journal, Vol. 23, No. 3, pp. 275-284.

5. Chen, H. L. (2011), "Does Board Independence Influence the Top Management Team? Evidence from Strategic Decisions toward Internationalization", Corporate Governance: An International Review, Vol. 19, No. 4, pp. 334-350.

6. Chittoor, R., Aulakh, P. S., Ray, S. (2015), "What drives overseas acquisitions by Indian firms? A behavioral risk-taking perspective", Management International Review, Vol. 55, No. 2, pp. 255-275.

7. Dauth, T., Tomczak, A. (2016), "Internationalization of top management teams: A comprehensive analysis of Polish stock-listed firms", Journal for East European Management Studies, Vol. 21, No. 2, pp. 167-183.

8. Georgakakis, D., Dauth, T., Ruigrok, W. (2016), "Too much of a good thing: Does international experience variety accelerate or delay executives' career advancement?", Journal of World Business, Vol. 51, No. 3, pp. 425-437.

9. Greve, P., Nielsen, S., Ruigrok, W. (2009), "Transcending borders with international top management teams: A study of European financial multinational companies", European Management Journal, Vol. 27, No. 3, pp. 213-224.

10. Herrmann, P., Datta, D. K. (2002), "CEO successor characteristics and the choice of foreign market entry mode: An empirical study", Journal of International Business Studies, Vol. 33, No. 3, pp. 551-569.

11. Herrmann, P., Datta, D. K. (2005), "Relationships between top management team characteristics and international diversification: An empirical investigation", British Journal of Management, Vol. 16, No. 1, pp. 69-78.

12. Herrmann, P., Datta, D. K. (2005), "Relationships between top management team characteristics and international diversification: An empirical investigation", British Journal of Management, Vol. 16, No. 1, pp. 69-78.

13. Hsu, W. T., Chen, H. L., Cheng, C. Y. (2013), "Internationalization and firm performance of SMEs: The moderating effects of CEO attributes", Journal of World Business, Vol. 48, No. 1, pp. 1-12.

14. Hutzschenreuter, T., Horstkotte, J. (2013), "Performance effects of international expansion processes: The moderating role of top management team experiences", International Business Review, Vol. 22, No. 1, pp. 259-277.

15. Kaczmarek, S., Ruigrok, W. (2013), "In at the Deep End of Firm Internationalization", Management International Review, Vol. 53, No. 4, pp. 513534. 
16. Kirca, A. H., Hult, G. T. M., Deligonul, S., Perryy, M. Z., Cavusgil, S. T. (2012), "A multilevel examination of the drivers of firm multinationality: A meta-analysis", Journal of Management, Vol. 38, No. 2, pp. 502-530.

17. Laufs, K., Bembom, M., Schwens, C. (2016), "CEO characteristics \& SME foreign market entry mode choice: The moderating effect of firm's geographic experience and host-country political risk", International Marketing Review, Vol. 33, No. 2, pp. 246-275.

18. Lee, H. U., Park, J. H. (2006), "Top team diversity, internationalization and the mediating effect of international alliances", British Journal of Management, Vol. 17, No. 3, pp. 195-213.

19. Lee, H. U., Park, J. H. (2008), "The influence of top management team international exposure on international alliance formation", Journal of Management Studies, Vol. 45, No. 5, pp. 961-981.

20. Lin, W. T., Liu, Y. S. (2012), "Successor characteristics, change in the degree of firm internationalization, and firm performance: The moderating role of environmental uncertainty", Journal of Management \& Organization, Vol. 18, No. 1, pp. 16-35.

21. Michailova, S (2010). Upper echelons in the People's Republic of China: evidence from the 15 largest companies. In Wang Y., Ramburuth, P. (Ed.) Thirty years of China's economic reform: Institutions, management organizations and foreign investment, London; Nova Science, pp. 115-138.

22. Miner, A. S., Gong, Y., Baker, T., O'Toole, J. (2011), "How does TMT prior experience shape strategy? A routine-based framework based on evidence from founding teams". In Carpenter, M. A. (Ed.) The handbook of research on top management teams. Cheltenham: Edward Elgar, pp.189-213.

23. Nielsen, B. B., Nielsen, S. (2011), "The role of top management team international orientation in international strategic decision-making: The choice of foreign entry mode", Journal of World Business, Vol. 46, No. 2, pp. 185-193.

24. Nielsen, S., (2010), "Top Management Team Internationalization and Firm Performance", Management International Review, Vol. 50, No. 2, pp. 185-206.

25. Patzelt, H., Knyphausen-AufseB, Z., Nikol, P., (2008), „Top management teams, business models, and performance of biotechnology ventures: An upper echelon perspective", British Journal of Management, Vol. 19, No. 3, pp. 205-221.

26. Patzelt, H., zu Knyphausen-AufseB, D., Fischer, H. T. (2009), "Upper echelons and portfolio strategies of venture capital firms", Journal of Business Venturing, Vol. 24, No. 6, pp. 558-572.

27. Piaskowska, D., Trojanowski, G. (2014), "Twice as Smart? The Importance of Managers' Formative-Years' International Experience for their International Orientation and Foreign Acquisition Decisions", British Journal of Management, Vol. 25, No. 1, pp. 40-57.

28. Rivas, J. L. (2012), "Board versus top management team international experience: a study of their joint effects", Cross Cultural Management: An International Journal, Vol. 19, No. 4, pp. 546-562.

29. Ruzzier, M., Antoncic, B., Hisrich, R. D., Konecnik, M. (2007), "Human capital and SME internationalization: A structural equation modeling study", Canadian Journal of Administrative Sciences/Revue Canadienne des Sciences de l'Administration, Vol. 24, No. 1, pp. 15-29.

30. Sambharya, R. B. (1996), "Foreign experience of top management teams and international diversification strategies of US multinational companies", Strategic Management Journal, Vol. 17, No. 9, pp. 739-746. 
31. Sanders, W., Tuschke, A, (2011). Corporate Elite Career Experiences and Strategic Preferences: The Case of The Chinese Corporate Governance Reform. In Carpenter, M. A. (Ed.) The handbook of research on top management teams. Cheltenham: Edward Elgar, pp.214-259.

32. Schmid, S., Dauth, T. (2014), "Does internationalization make a difference? Stock market reaction to announcements of international top executive appointments", Journal of World Business, Vol. 49, No. 1, pp. 63-77.

33. Schmid, S., Wurster, D. J. (2015), "Internationalisation of upper echelons in different institutional contexts: top managers in Germany and the UK", European Journal of International Management, Vol. 9, No. 4, pp. 510-535.

34. Schmid, S., Wurster, D. J. (2016) "Are international top executives paid more? Empirical evidence on fixed and variable compensation in management boards of German MNCs", European Journal of International Management, Vol. 10, No. 1, pp. 25-53.

35. Slater, D. J., Dixon-Fowler, H. R. (2009), "CEO International Assignment Experience and Corporate Social Performance", Journal of Business Ethics, Vol. 89, No. 3, pp. 473-489.

36. Villar, C., Linares-Navarro, E., Toral, D. (2010), "New models of internationalization in small traditional manufacturing firms", In PlaBarber J., Alegre J. (Ed.) Reshaping the Boundaries of the Firm in an Era of Global Interdependence. Emerald Group Publishing Limited, pp. 75-96.

37. Wang, H., Feng, J., Liu, X., Zhang, R. (2011), "What is the benefit of TMT's governmental experience to private-owned enterprises? Evidence from China", Asia Pacific Journal of Management, Vol. 28, No. 3, pp. 555-572.

38. Wang, X., Ma, L., Wang, Y. (2015), "The impact of top management team functional background on firm performance: Evidence from listed companies in China's IT industry", Nankai Business Review International, Vol. 6, No. 3, pp. 281 311.

\section{About the author}

Dino Đerđa serves as a Board Member of couple of Croatian companies mainly in pharmaceutical and cosmetics industry. He attends doctoral program at Faculty of Economics \& Business - Zagreb. His main research field is strategic management, corporate governance, entrepreneurship and SME's internationalization. The author can be reached at d.djerdja@gmail.com. 